\title{
RUMAH Sakit Umum SWASTa Kelas C Dengan FASILITAS TAMAN TERAPI DI KABUPATEN WONOGIRI
}

\author{
Jean Elisabet Tambunan, Ahmad Farkhan, Sri Yuliani \\ Program Studi Arsitektur \\ Fakultas Teknik \\ Universitas Sebelas Maret Surakarta \\ Email : jeantambunan@gmail.com
}

\begin{abstract}
Designing Private General Hospital Class $C$ in the Kabupaten Wonogiri motivated by needs of society to have better health services, the increased of population growth was offset by increasing the number of health facilities, the spread of hospital in Wonogiri is unequal, Kabupaten Wonogiri is lack of 283 beds, the rumors about reduction of hospitals grade with facilities of Badan Penyelenggara Jaminan Sosial. The purpose of this design is to generate design of hospital buildings as a place for people of Wonogiri and communities outside Wonogiri, to obtain health facilities as the main reference with the capability of service that are adjusted to the regulation standard of Class $C$ Hospital by using a healing garden as a healing facility or therapy. So far, the existing paradigm regarding hospital is the patients often feel uncomfortable when receiving medical and treatment due to the circumstances of the hospital which is seemed creepy and claustrophobic for patients. So it can trigger stress of them which can cause patient's immune system becomes depressed so that the process of recovery and healing the patient became obstructed. The method used is a method of designing the architecture, applied to the hospital building with characteristics of physical environment of a hospital facility must be designed by emphasizing the comfortability and safety for patients, with healing garden facilities aims to reduce stress levels of patients who will be treated at the hospital.
\end{abstract}

Keywords: Healing Garden, Hospital, Health Facilities, Healing Facilities, Types of Plant.

\section{PENDAHULUAN}

Menurut UU No. 36 Tahun 2009 Tentang Rumah Sakit, kesehatan adalah keadaan sehat, baik secara fisik, mental, spiritual maupun sosial yang memungkinkan setiap orang untuk hidup produktif secara sosial dan ekonomis. Dalam rangka peningkatan pembangunan nasional, peningkatan akses masyarakat terhadap layanan kesehatan yang berkualitas merupakan salah satu agenda dari upaya mewujudkan Indonesia sejahtera yang harus didukung dengan upaya peningkatan kualitas fasilitas kesehatan.

Menurut UU No. 44 Tahun 2009 Tentang Kesehatan, rumah sakit merupakan salah satu sarana kesehatan sebagai tempat menyelenggarakan upaya kesehatan secara profesional yang pelayanannya disediakan oleh dokter, perawat, dan tenaga ahli kesehatan lainnya dalam menangani masalah medik untuk pemulihan dan pemeliharaan kesehatan yang baik. Rumah sakit sebagai salah satu fasilitas pelayanan kesehatan merupakan bagian dari sumber daya kesehatan yang sangat diperlukan dalam mendukung penyelenggaraan upaya kesehatan dengan karakteristik dan organisasi yang sangat kompleks.

Pertumbuhan penduduk Indonesia yang semakin pesat, menjadikan kurang terlayaninya fasilitas kesehatan di beberapa daerah. Hal ini menjadikan kebutuhan Rumah Sakit menjadi meningkat mengingat kebutuhan fasilitas kesehatan berbanding lurus dengan jumlah penduduk yang terus meningkat. Semakin meningkat pertumbuhan penduduk maka semakin meningkat juga kebutuhan akan fasilitas kesehatan yakni rumah sakit.

Kabupaten Wonogiri terdiri dari 25 kecamatan dan saat ini jumlah rumah sakit yang tersedia di Kabupaten Wonogiri terdapat 9 rumah sakit yang terdiri dari 1 rumah sakit milik pemerintah dan 8 rumah sakit lainnya dikelola oleh pihak swasta (Dinas Kesehatan 
Kab. Wonogiri, 2014) yang persebarannya tidak merata mengingat masih ada beberapa kecamatan yang tingkat kepadatan penduduknya cukup tinggi, namun belum mendapatkan fasilitas kesehatan seperti Kecamatan Jatisrono, Kecamatan Ngadirojo, Kecamatan Tirtomoyo dan Kecamatan Purwantoro.

Berdasarkan data BPS Kabupaten Wonogiri 2012, jumlah penduduk Kabupaten Wonogiri sebesar 928,904 jiwa, saat ini terdapat 9 rumah sakit dengan total TT sebanyak 646 tempat tidur (TT), dan masih kekurangan 283 TT. Menurut Kemenkes, 2012 idealnya jumlah TT di suatu kabupaten dihitung berdasarkan jumlah penduduk, yakni dengan asumsi 1 TT per 1000 penduduk, sehingga jumlah TT yang dibutuhkan Kabupaten Wonogiri sebanyak 929 TT. Rumah sakit kelas $\mathrm{C}$ adalah rumah sakit yang cocok didirikan di Kabupaten Wonogiri karena kebutuhan tempat tidurnya yang berada pada kisaran 100-200 TT.

Masyarakat Kabupaten Wonogiri yang hendak berobat di rumah sakit setempat harus dirujuk ke rumah sakit di kota seperti Solo dan sekitarnya karena ketersediaan tempat tidur masih belum memenuhi dengan fasilitas yang masih kurang memadahi.

Penyediaan fasilitas terapi di rumah sakit akan lebih efektif bagi kesembuhan pasien dengan mengandalkan lingkungan dan alam sebagai komponen pendukung dalam proses penyembuhan. Taman terapi atau orang lebih mengenal dengan sebutan Healing Garden, memanfaatkan ruang terbuka dalam lingkungan rumah sakit dengan konsep back to nature yang menyediakan beberapa jenis tanaman yang akan membantu proses penyembuhan pasien (Cooper, 2006). Taman terapi merupakan taman yang dapat merestorasi penggunanya dari stres dan mempunyai pengaruh yang positif baik bagi pasien, pengunjung, maupun perawat (Hebert, 2003).

Dapat disimpulkan bahwa dengan adanya rencana pembangunan rumah sakit yang baru ini, maka diharapkan sebuah desain arsitektur rumah sakit dapat tercipta dengan baik, sebagai sebuah respon terhadap meningkatnya kebutuhan lingkungan akan fasilitas pelayanan kesehatan.

\section{METODE}

A. Macam dan Teknik Pengumpulan Data

1. Data Topografi: didapat melalui observasi dan dokumentasi rupa muka tanah, selain itu data juga didapat melalui data instansional pemerintah kota serta melalui situs dan artikel terkait.

2. Data Kewilayahan: didapat melalui data instansional pemerintah kota serta melalui situs dan artikel terkait.

3. Kondisi Rumah Sakit: didapat dengan observasi dan dokumentasi beberapa rumah sakit yang ada serta wawancara dengan sumber yang terpercaya. Data lain didapat dari situs resmi sirs.buk.depkes.go.id, serta dari artikel terkait.

4. Standar Rumah Sakit: didapat dari Pedoman Teknis Sarana Dan Prasarana Rumah Sakit Kelas C.

5. Konsep Taman Terapi: data didapat dari beberapa buku referensi.

\section{B. Metode Analisis Data}

Analisis perencanaan (building concept) mengidentifikasi masalah yang ada berdasarkan konsep rancangan rumah sakit umum kelas $\mathrm{C}$ yang diselesaikan dengan fasilitas taman terapi namun tetap memperhatikan unsur fungsional bangunan rumah sakit kelas $\mathrm{C}$.

Analisis perancangan (building criteria) dilakukan dengan mengolah data yang telah terkumpul dan dikelompokkan berdasarkan pemrograman fungsional, performasi, dan arsitektural.

1. Pemrograman fungsional bertujuan untuk mengidentifikasi penggunaan rumah sakit, di antaranya pelaku kegiatan, jenis kegiatan, pola kegiatan, dan sifat kegiatan.

2. Pemrograman performasi menerjemahkan secara sistematik kebutuhan para pengguna rumah sakit berserta fasilitasnya ke dalam persyaratan pemilihan tapak, persyaratan kebutuhan ruang, persyaratan besaran ruang dan program ruang, serta penataan lansekap dalam tapak bangunan untuk mendapatkan bangunan yang direncanakan. 
3. Analisis arsitektural merupakan tahap penggabungan dari hasil identifikasi kedua analisa sebelumnya (fungsional dan performasi). Dalam proses ini akan menganalisa masalah massa, ruang, tampilan, pengolahan tapak, utilititas, dan struktur bangunan.

\section{ANALISIS}

\section{A. Analisis Peruangan}

Analisis kebutuhan ruang didasarkan pada kegiatan-kegiatan yang diwadahi di Rumah Sakit Umum Kelas C. Perhitungan besaran ruang berdasarkan pembagian enam zona, meliputi zona pelayanan medik, zona penunjang medik, zona penunjang non medik, zona penunjang umum, zona servis, dan zona taman terapi (Tabel 1).

Tabel 1. Kebutuhan Ruang

\begin{tabular}{|c|c|c|}
\hline $\begin{array}{l}\text { KELOMPOK } \\
\text { KEGIATAN }\end{array}$ & $\begin{array}{l}\text { INSTALASI } \\
\text { RUANG }\end{array}$ & $\begin{array}{l}\text { BESARAN } \\
\text { RUANG }\end{array}$ \\
\hline \multirow{8}{*}{$\begin{array}{l}\text { Zona } \\
\text { Pelayanan } \\
\text { Medik dan } \\
\text { Perawatan }\end{array}$} & Ruang Rawat Jalan & \multirow[t]{8}{*}{$10.989 \mathrm{~m}^{2}$} \\
\hline & Ruang Gawat Darurat & \\
\hline & Ruang Rawat Inap & \\
\hline & (IRNA) & \\
\hline & $\begin{array}{l}\text { Ruang Perawatan } \\
\text { Intensif }\end{array}$ & \\
\hline & Ruang Operasi (COT/ & \\
\hline & $\begin{array}{l}\text { Central Operation } \\
\text { Theatre) }\end{array}$ & \\
\hline & Ruang Kebidanan & \\
\hline \multirow{3}{*}{$\begin{array}{l}\text { Zona } \\
\text { Penunjang } \\
\text { Medik }\end{array}$} & Ruang Farmasi & \multirow[t]{3}{*}{$1.992,6 \mathrm{~m}^{2}$} \\
\hline & Ruang Laboratorium & \\
\hline & $\begin{array}{l}\text { Ruang Rehabilitasi } \\
\text { Medik }\end{array}$ & \\
\hline $\begin{array}{l}\text { Zona } \\
\text { Penuniang }\end{array}$ & $\begin{array}{l}\text { Bagian Administrasi } \\
\text { dan Akuntansi }\end{array}$ & \multirow[t]{2}{*}{$1.144,55 \mathrm{~m}^{2}$} \\
\hline Non Medik & Ruang serbaguna & \\
\hline $\begin{array}{l}\text { Zona } \\
\text { Penunjang } \\
\text { Umum }\end{array}$ & Bagian Umum & $512,79 \mathrm{~m}^{2}$ \\
\hline \multirow[t]{7}{*}{ Zona Servis } & $\begin{array}{l}\text { Ruang Sterilisasi } \\
\text { Pusat (CSSD/ Central } \\
\text { Supply Sterilization } \\
\text { Departement) }\end{array}$ & \multirow[t]{7}{*}{$2.210,77 \mathrm{~m}^{2}$} \\
\hline & $\begin{array}{l}\text { Ruang Pemulasaraan } \\
\text { Jenazah dan Forensik }\end{array}$ & \\
\hline & $\begin{array}{l}\text { Ruang Dapur Utama } \\
\text { Dan Gizi Klinik }\end{array}$ & \\
\hline & Ruang Pencucian & \\
\hline & Linen/ Laundri & \\
\hline & Ruang Sanitasi & \\
\hline & $\begin{array}{l}\text { Ruang Pemeliharaan } \\
\text { Sarana (Bengkel }\end{array}$ & \\
\hline
\end{tabular}

\begin{tabular}{|l|l|l|}
\hline & $\begin{array}{l}\text { Mekanikal \& } \\
\text { Elektrikal/ } \\
\text { Workshop) }\end{array}$ & \\
\hline Area Parkir & $3.349,8 \mathrm{~m}^{2}$ \\
\hline Zona Taman Terapi & $10.099,755 \mathrm{~m}^{2}$ \\
\hline
\end{tabular}

\section{B. Analisis Lokasi}

Proses analisis penentuan lokasi terkait dengan kondisi wilayah setempat yang mendukung keberadaan rumah sakit dan disesuaikan dengan Rencana Umum Tata Rencana Kota/ Master Plan Kabupaten Wonogiri.

1. Tujuan :

Mendapatkan kriteria-kriteria lokasi yang sesuai dengan tempat dan kedudukan sebuah bangunan rumah sakit.

2. Dasar pertimbangan :

Tata guna lahan diperuntukan bagi kawasan pelayanan jasa dan sosial, bebas dari gangguan lingkungan, luasan tapak mampu mewadahi semua kegiatan dalam rumah sakit.

3. Proses Analisis :

Rumah sakit terletak di salah satu kecamatan dari 25 kecamatan yang ada di Kabupaten Wonogiri yaitu Kecamatan Ngadirojo, Desa Kaliampo. Penggunaan lahan atau peruntukan lahan yaitu sebagai fasilitas umum, fasilitas sosial, fasilitas pelayanan jasa, pemukiman, dan perkantoran.

Lokasi terpiih berada di daerah perkebunan, pemukian penduduk dan perkantoran.

Luas lahan terpilih $34.433,75 \mathrm{~m}^{2}$ dengan Garis Sempadan Bangunan (GSB) sebesar $1 / 2$ dari lebar jalan, maka GSB minimal sebesar $1 / 2 \times 7$ $\mathrm{m}=3,5 \mathrm{~m}$ (Gambar 1).

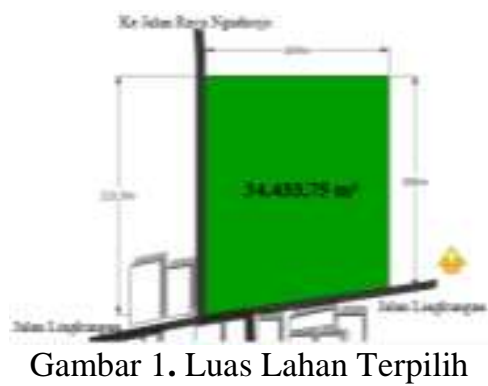


C. Analisis Pencapaian

Pencapaian ke dalam bangunan harus mudah diakses melalui jalur utama, mudah dilihat, dan memiliki sirkulasi yang aman.

1. Tujuan :

Mendapatkan Main Entrance (ME) sebagai pintu masuk utama dan Side Entrance (SE) sebagai pintu masuk menuju area servis.

2. Dasar pertimbangan:

Arus kendaraan, keamanan dan kemudahan akses, potensi jalan, serta tingkat keamanan.

3. Proses Analisis :

ME in ditujukan untuk jalur masuk bagi pasien dan pengunjung. ME out ditujukan untuk jalur keluar bagi pasien dan pengunjung. SE (Side Entrance) in dan out ditujukan untuk jalur masuk dan keluar bagi tenaga medis, karyawan, dan kendaraan servis (Gambar 2).

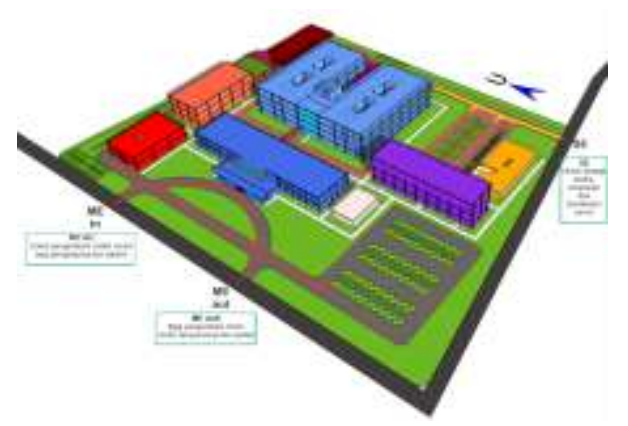

Gambar 2. Pola Pencapaian

D. Analisis Pemintakatan (Penzoningan)

Pemintakatan berdasarkan sifat kegiatan dan tingkat kebisingan pada tapak sebagai pedoman dalam penataan ruang.

1. Tujuan :

Mendapatkan tata letak massa pada bangunan rumah sakit yang direncanakan.

2. Dasar Pertimbangan :

Karaktrer dan perilaku pengguna

bangunan, kelompok (zona)

kegiatan, ketersediaan $50 \%$ area

penghijauan (Hatmoko, 2010) sebagai taman terapi.

3. Proses Analisis :
Berdasarkan analisis yang telah dilakukan, secara umum zoning dibagi dalam 6 bagian yaitu Zona Pelayanan Medik, Zona Penunjang Medik, Zona Penunjang Non Medik, Zona Penunjang Umum, Zona Servis dan Zona Parkir (Tabel 2).

Tabel 2. Persyaratan Ruang

\begin{tabular}{|l|c|c|c|}
\hline $\begin{array}{c}\text { Fungsi } \\
\text { Kegiatan }\end{array}$ & $\begin{array}{c}\text { Sangat } \\
\text { Tenang }\end{array}$ & $\begin{array}{c}\text { Cukup } \\
\text { Tenang }\end{array}$ & $\begin{array}{c}\text { Tidak } \\
\text { Tenang }\end{array}$ \\
\hline $\begin{array}{l}\text { Zona Pelayanan } \\
\text { Medik }\end{array}$ & $\checkmark$ & & \\
\hline $\begin{array}{l}\text { Zona Penunjang } \\
\text { Medik }\end{array}$ & $\checkmark$ & & \\
\hline $\begin{array}{l}\text { Zona Penunjang } \\
\text { Non Medik }\end{array}$ & & $\checkmark$ & \\
\hline $\begin{array}{l}\text { Zona Penunjang } \\
\text { Umum }\end{array}$ & & $\checkmark$ & \\
\hline Zona Servis & & & $\checkmark$ \\
\hline Zona Parkir & & & $\checkmark$ \\
\hline $\begin{array}{l}\text { Zona Taman } \\
\text { Terapi }\end{array}$ & & $\checkmark$ & \\
\hline
\end{tabular}

E. Analisis Gubahan Massa dan Tampilan Bangunan

1. Analisis Gubahan Massa

Bentuk massa menggunakan bentuk dasar persegi yang memenuhi karakter bangunan Rumah Sakit dengan penambahan unsur lingkaran untuk mempermudah sirkulasi dalam bangunan. Bentuk persegi memiliki efisiensi ruang yang tinggi sesuai dengan fleksibilitas ruang-ruang dalam rumah sakit. Bentuk lingkaran yang dinamis diterapkan dalam sirkulasi bangunan rumah sakit untuk menunjang kemudahan gerak putar dan sirkulasi (Gambar 3).

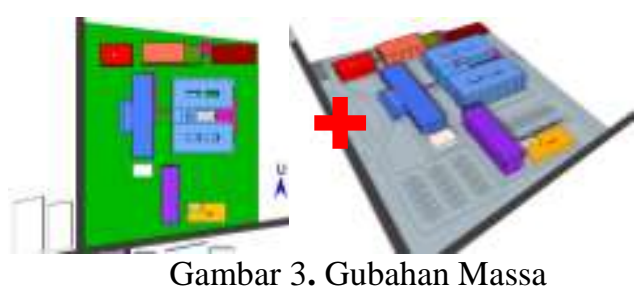

2. Tampilan Bangunan

a. Menggunakan konsep ruang terbuka pada Ruang IGD, Ruang Rawat Jalan, dan Ruang Rawat 
Inap dengan menghadirkan taman dalam bangunan maupun luar bangunan sebagai taman terapi (Gambar 4).

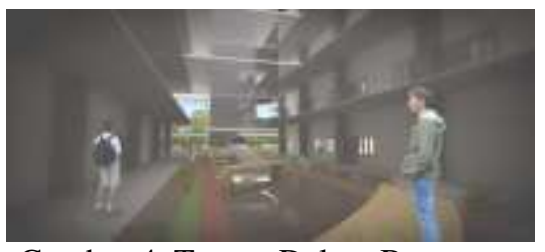

Gambar 4. Taman Dalam Bangunan

b. Pada bagian taman dalam bangunan tidak menggunakan penutup bangunan, yang bertujuan sebagai penghawaan alami dan pencahayaan alami dalam bangunan, selain itu agar pasien tidak merasa terkekang ketika ada dalam bangunan tersebut (Gambar 5).

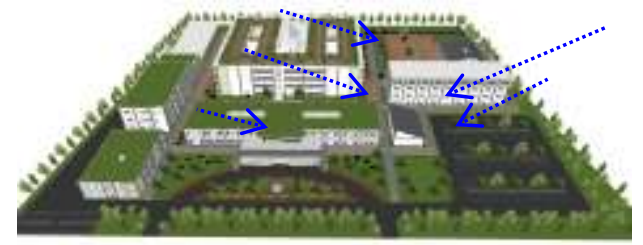

Gambar 5. Penghawaan Alami

c. Fasilitas roof garden pada area Rawat Inap yang dapat diakses langsung oleh pasien dan roof garden pada area IGD, Rawat Jalan, dan area Pelayanan Medik (Gambar 6).

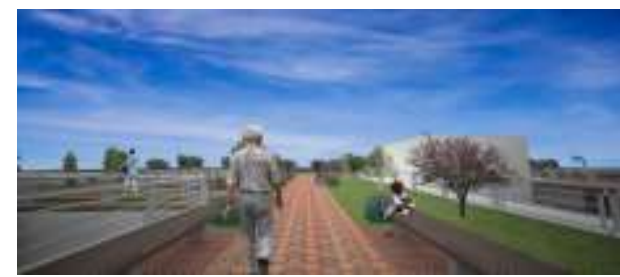

Gambar 6. Fasilitas Roof Garden

\section{F. Analisis Elemen Ruang}

Beberapa ruang dalam rumah sakit perlu mendapat perhatian mengingat penggunanya adalah pasien yang mengalami gangguan kesehatan. Prinsip yang digunakan dalam merencanakan interior ruang adalah dengan membedakan karakter ruang yang hangat dan dingin. Karakter hangat dapat diterapkan pada ruangruang yang bersifat privat yaitu ruang perawatan. Untuk menciptakan karakter hangat dalam ruangan, dapat menggunakan warna-warna seperti krem, orange pada unsur-unsur interior seperti dinding dan lantai (Gambar 7).

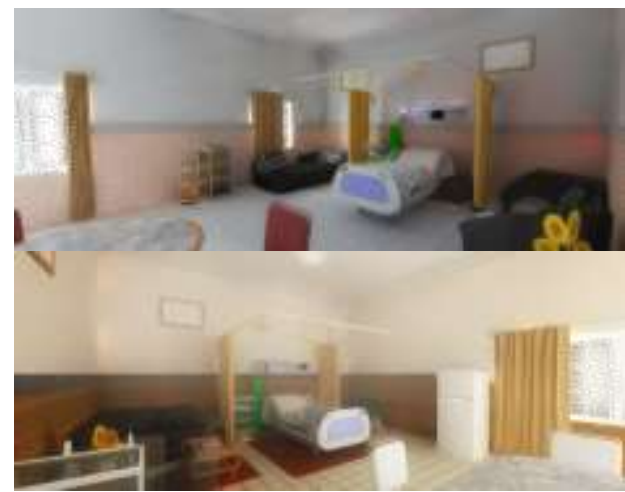

Gambar 7. Karakter Hangat Dalam Ruang Rawat Inap

G. Analisis Lansekap

1. Tujuan

Mendapatkan jenis tanaman dan elemen pembentuk lansekap yang sesuai dan tepat untuk diterapkan pada taman terapi rumah sakit.

2. Dasar Pertimbangan

Tanaman tidak boleh beracun, berduri, bergetah, hindari penggunaan tanaman yang menyebarkan serbuk bunga yang dapat menyebabkan alergi.

3. Proses Analisis

Memanfaatkan $50 \%$ tapak sebagai RTH berupa taman yang diletakkan di sekeliling bangunan dan di pusat bangunan sebagai taman terapi. Hal ini bertujuan untuk mendukung penyembuhan pasien. Jenis tanaman dipilih sesuai dengan kriteria taman terapi kemudian ditata sedemikian rupa agar dapat memberikan kenyamanan bagi pasien dalam proses penyembuhan (Gambar 8). 


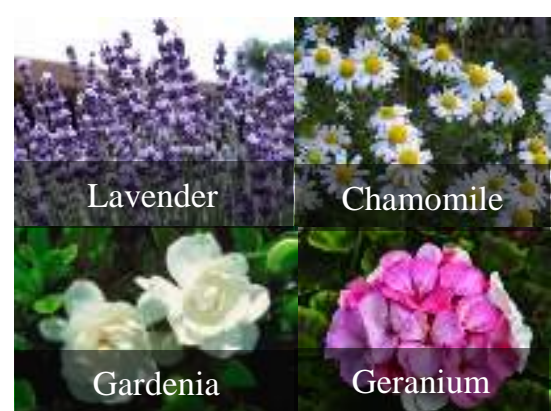

Gambar 8. Jenis Tanaman Terpilih

Vegetasi peneduh untuk memberikan pembayangan pada area sekitarnya yang ditempatkan pada area terapi outdoor, parkir, dan sirkulasi pedestrian, seperti: pohon ketapang, pohon bougenvil, pohon flamboyan (Gambar 9).

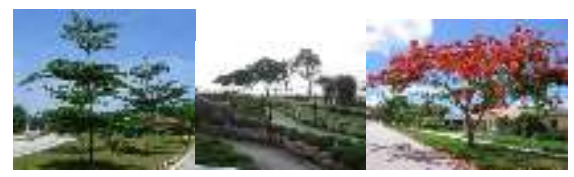

Gambar 9. Macam Vegetasi Peneduh

Pemanfaatan kolam dan air mancur diaplikasikan pada entrance rumah sakit, area taman terapi, area refleksi kaki, dan taman area timur. Adanya elemen air dalam taman ini dapat menjadi terapi pendengaran pada pasien sehingga pasien merasa lebih tenang dan santai. Elemen batuan berfungsi sebagai unsur yang dapat membantu pasien dalam proses penyembuhan dengan menggukannya sebagai alat refleksi kaki.

\section{H. Analisis Utilitas}

Utilitas merupakan bagian penting dalam perancangan rumah sakit. Berikut analisis mengenai sistem air bersih, sistem pembuangan air limbah, sistem pengolahan limbah medis, dan sistem gas medis.

1. Sistem Air Bersih

Sistem air bersih pada perencanaan bangunan Rumah Sakit yang direncanakan menggunakan sistem down feed distribution dengan pasokan air yang berasal dari PAM dan sumur (Gambar 10).

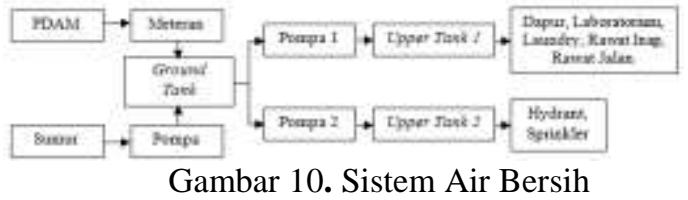

Gambar 10. Sistem Air Bersih

2. Sistem Pembuangan Air Limbah

a. Black Water, air limbah yang tidak dapat dipergunakan lagi, contohnya air bekas BAB (Gambar 11).

wC $\rightarrow$ Septistank $\rightarrow$ Peressaun $\rightarrow$ Riol Kota Gambar 11. Sistem Black Water

b. Grey Water, berasal dari air buangan cuci, air buangan wastafel, air bekas wudhu, air limbah masak-memasak, dan lainnya (Gambar 12).

c.

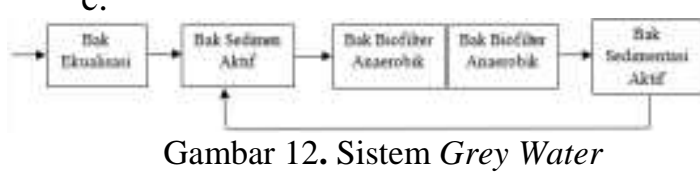

d. Air Kotor Mengandung Bahan Kimia, menurut http://www.kelair.bppt.go.id/ memerlukan pengolahan khusus sebelum dibuang untuk menghindari pencemaran (Gambar 13).

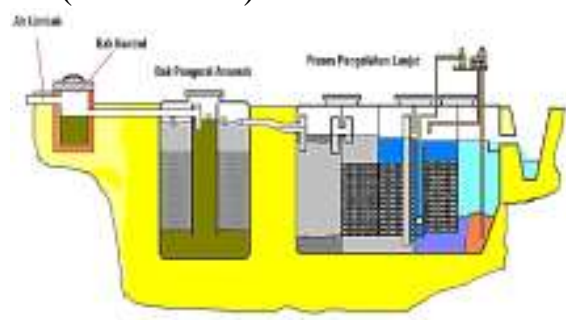

Gambar 13. Sistem Air Kotor Mengandung Bahan Kimia

3. Sistem Pengolahan Limbah Medis Limbah medis adalah limbah yang langsung dihasilkan dari tindakan diagnosis dan tindakan medis terhadap pasien, berasal dari ruang poliklinik, perawatan, bedah, kebidanan, otopsi, dan ruang laboratorium (Gambar 14). 


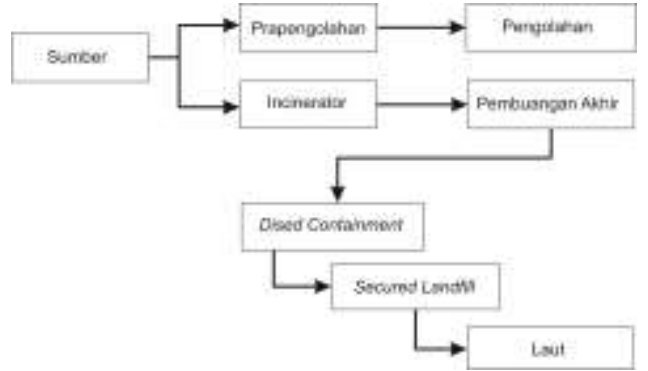

Gambar 14. Sistem Pengolahan Limbah Medis

4. Sistem Gas Medis Jenis-jenis instalasi gas medis yang biasa dipasang untuk keperluan rumah sakit adalah: Oxygen $(\mathrm{O} 2)$, Nitrous Oxide (N2O), Medical Compressed Air (Breathing Air), Vacum (Suction) (Gambar 15).

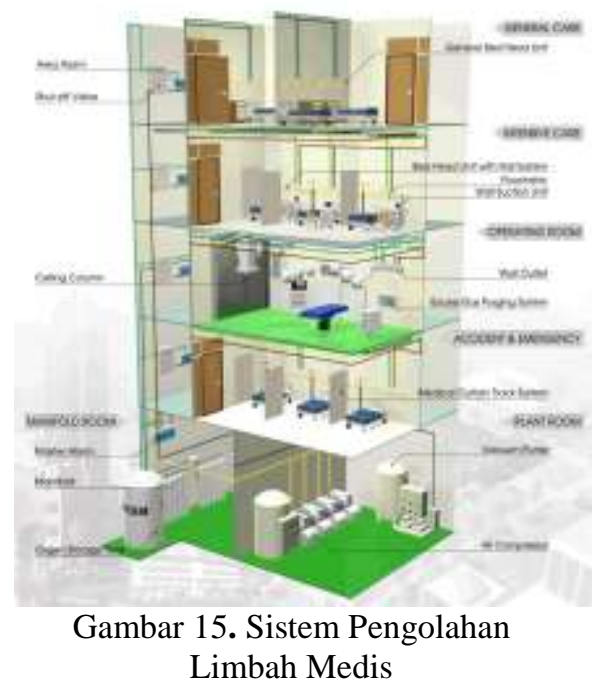

\section{KESIMPULAN (KONSEP DESAIN)}

Konsep rancangan Rumah Sakit Umum Kelas C dengan Fasilitas Taman Terapi merupakan perwujudan sebuah bangunan rumah sakit yang dirancang sebagai wadah bagi masyarakat Kabupaten Wonogiri maupun masyarakat di luar Kabupaten Wonogiri untuk mendapatkan fasilitas kesehatan sebagai rujukan utama dengan kemampuan pelayanan yang disesuaikan pada standar peraturan Rumah Sakit Kelas C dengan memanfaatkan taman terapi sebagai fasilitas penyembuhan atau terapi. Adanya fasilitas taman terapi bertujuan untuk menurunkan tingkat stres bagi pasien yang akan berobat di rumah sakit dengan menempatkan beberapa jenis tanaman yang dapat membantu menurunkan tingkat stres seseorang dan penambahan elemen lainnya sebagai penunjang dalam taman.

Dari hasil analisis serta hasil korelasi dari beberapa data di atas, maka diperoleh hasil berupa Rancangan Rumah Sakit Umum Kelas C di Kabupaten Wonogiri yang terlihat pada Lampiran 1., Lampiran 2., Gambar 16., Gambar17. dan Gambar 18.
Bangunan
Lokasi
: Rumah Sakit Umum Kelas C
: Kecamatan Ngadirojo, Kabupaten Wonogiri
Luas Lahan $: \pm 34.433,75 \mathrm{~m}^{2}$
Luas Bangunan : $\pm 20.199,51 \mathrm{~m}^{2}$
Daya Tampung : 250 Pasien
Fungsi
: Pelayanan Kesehatan Penyakit Umum

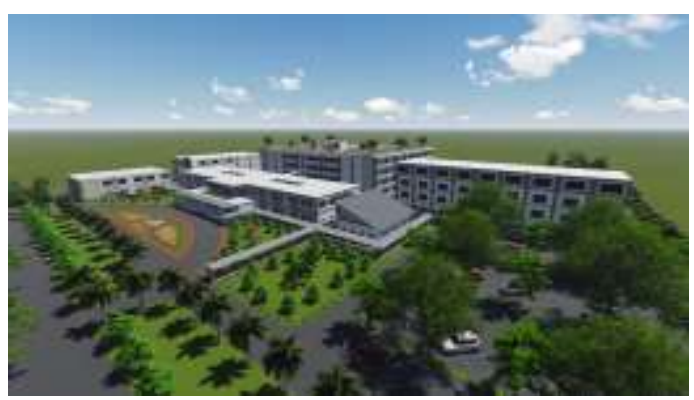

Gambar 16. Gambar Eksterior

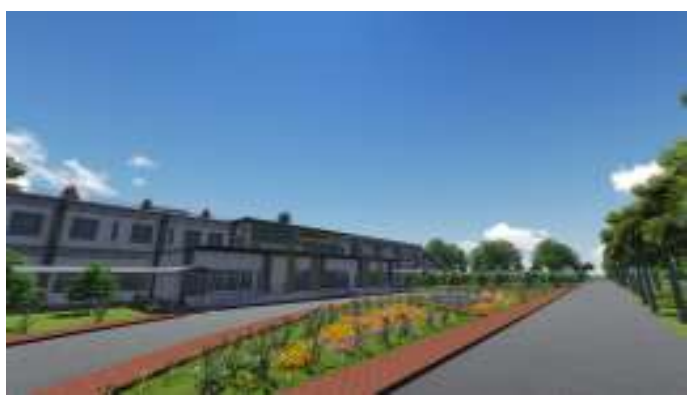

Gambar 17. Gambar Eksterior

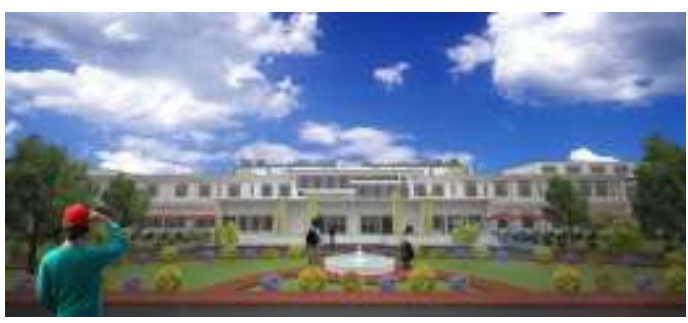

Gambar 18. Gambar Eksterior

Penerapan fasilitas taman terapi pada rumah sakit umum kelas $\mathrm{C}$ melalu penataan lansekap seperti yang terlihat pada Gambar 19 . dan Gambar 20. 


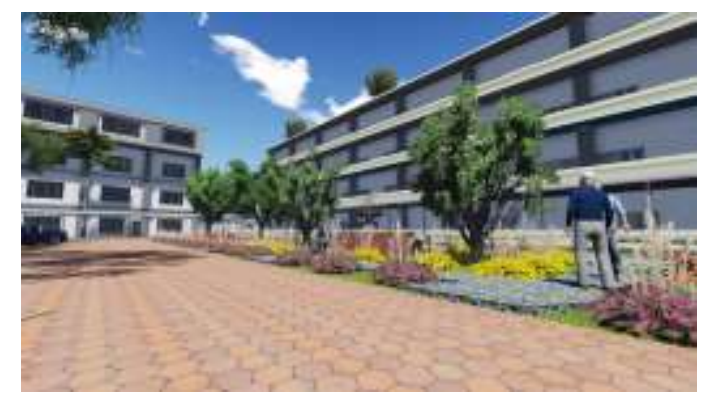

Gambar 19. Area Refleksi Kaki

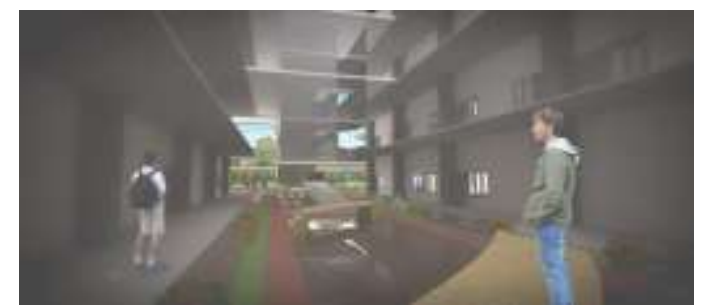

Gambar 20. Area Taman Terapi Dalam Bangunan

\section{REFERENSI}

BPS Kabupaten Wonogiri, 2012.

Cooper Marcus, C. 2006. Healing gardens in hospitals. in: C Wagenaar (Ed.) The architecture of hospitals.NAi Publishers, Rotterdam; 314-329.

Hatmoko, Adi Utomo, dkk. 2010. Arsitektur Rumah Sakit. Yogyakarta: Global Rancang Selaras.

Kementerian Kesehatan RI Direktorat Jendral Bina Upaya Kesehatan, 2012.

Pedoman Teknis Sarana Dan Prasarana Rumah Sakit Kelas C, Kementrian Departemen Kesehatan Republik Indonesia, 2007.

Undang-Undang No. 44 Tahun 2009 tentang Rumah Sakit.

Undang-Undang Republik Indonesia No. 36 Tahun 2009 tentang Kesehatan.

http://sirs.buk.depkes.go.id/rsonline/report/ http://www.bps.go.id/ http://TerapiWarna.html http://www.kelair.bppt.go.id/ 


\section{LAMPIRAN}

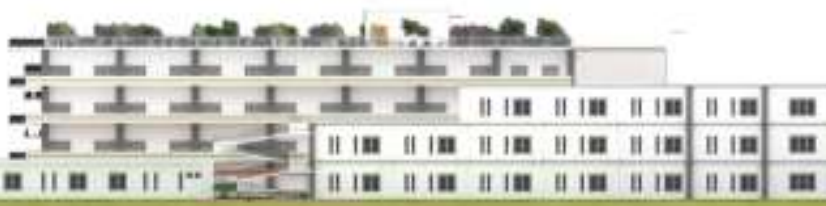

$\mathrm{mm} \mathrm{m} \mathrm{m} \mathrm{m} \mathrm{m} \mathrm{m} \mathrm{m}$

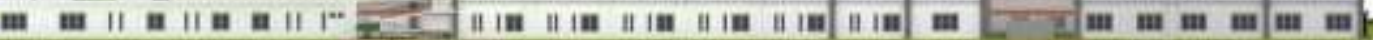

Tampak Utara

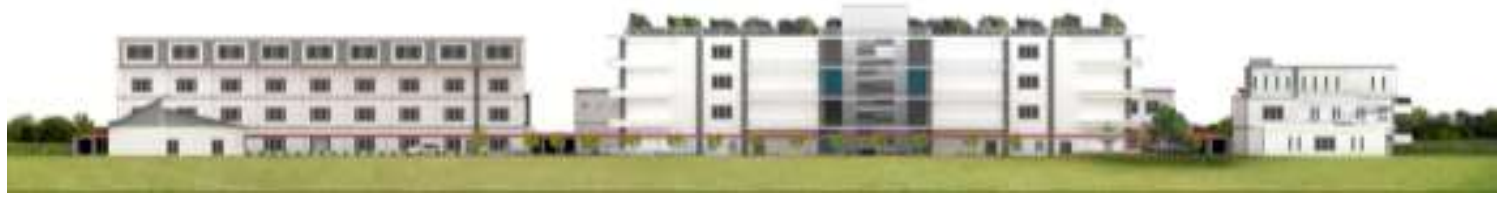

Tampak Selatan

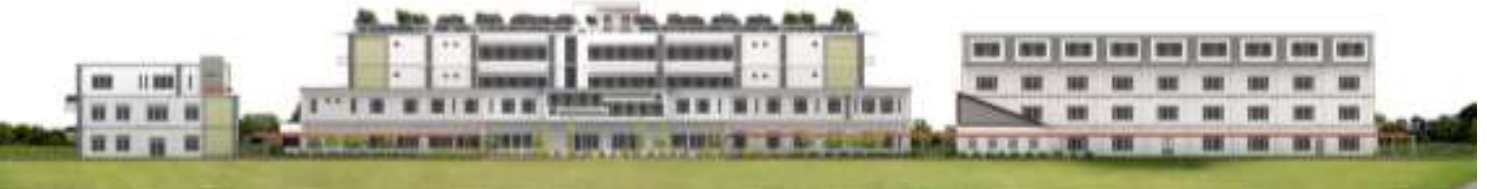

Tampak Barat

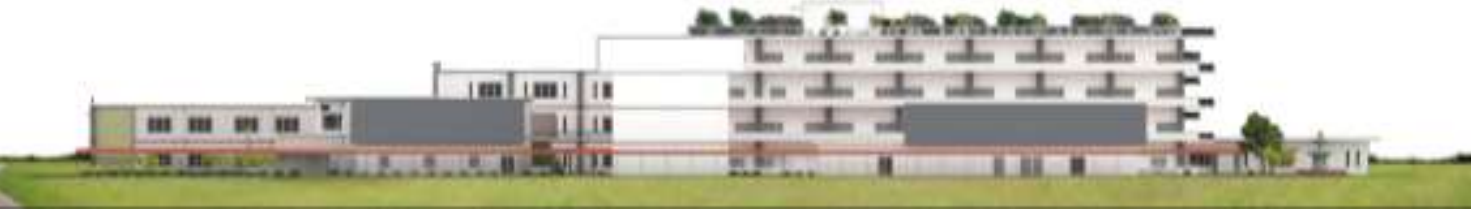

Lampiran 1. Tampak Rumah Sakit Umum Kelas C

Tampak Timur 


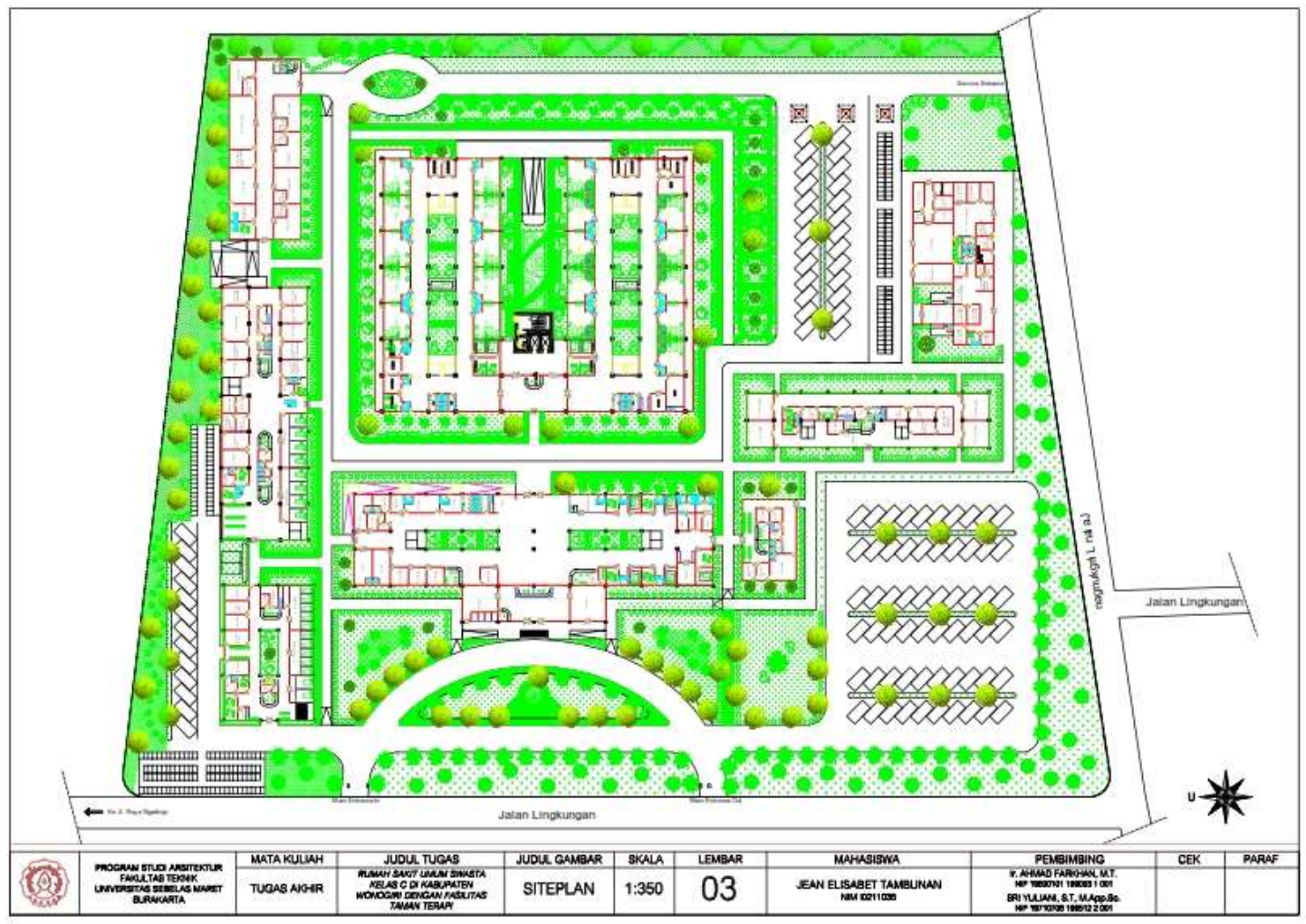

Lampiran 2. Rencana Tapak 